\title{
IMPROVING THE GRAMMATICAL ACCURACY OF THE SPOKEN ENGLISH OF INDONESIAN INTERNATIONAL KINDERGARTEN STUDENTS
}

\author{
Imelda Gozali \\ (imelda.surabaya@gmail.com) \\ Ignatius Harjanto \\ (ig.harjanto@gmail.com) \\ Universitas Katolik Widya Mandala \\ Jl. Dinoyo 42-44, Surabaya 60265
}

\begin{abstract}
The need to improve the spoken English of kindergarten students in an international preschool in Surabaya prompted this Classroom Action Research (CAR). It involved the implementation of Form-Focused Instruction (FFI) strategy coupled with Corrective Feedback (CF) in Grammar lessons. Four grammar topics were selected, namely Regular Plural form, Subject Pronoun, Auxiliary Verbs Do/Does, and Irregular Past Tense Verbs as they were deemed to be the morpho-syntax which children acquire early in life based on the order of acquisition in Second Language Acquisition. The results showed that FFI and CF contributed to the improvement of the spoken grammar in varying degrees, depending on the academic performance, personality, and specific linguistic traits of the students. Students with high academic achievement could generally apply the grammar points taught after the FFI lessons in their daily speech. Students who were rather talkative were sensitive to the $\mathrm{CF}$ and could provide self-repair when prompted. Those with lower academic performance generally did not benefit much from the FFI lessons nor the CF.
\end{abstract}

Keywords: form-focused instruction, corrective feedback, grammatical accuracy, kindergarten, teaching English to young learners. 
The rising trend in the use of English as the medium of instruction in Indonesia has spurred the growth of international and national plus schools. This is paralleled with the boom of international pre-school, one of which being the school in this study, which hereinafter shall be referred to as Pre-school X. English is the medium of instruction in all the lessons and other daily school activities in this school. In the past years, the school principal received feedback from primary school teachers and parents of Pre-school X alumni, who commented that Pre-school X students are quite fluent in speaking English, but with 'chaotic' grammar. In response to that, the school has incorporated a new subject called Grammar to be taught to the Kindergarten 2 (K2) students since October 2012. In this subject, simple grammatical items were introduced by the Grammar teacher using explicit instruction, games, and written exercise. However, it was observed that although the students seemed to have mastered the forms taught during Grammar classroom exercises, the same students still showed slips of those forms in spontaneous speech. Therefore, explicit Grammar instruction alone, in the way that has been given since October 2012, might not suffice for improving the accuracy of the children's spontaneous talks.

Literature review revealed that Form-Focused Instruction (FFI) for Grammar teaching is gaining ground. FFI approach was found to be more effective than merely isolated grammar instruction or communicative tasks without drawing the attention on grammar (Spada \& Lightbown, 1994). It is also supported by cognitive theories like that of McLaughlin's (1987), which purported that FFI promotes the restructuring process in the L2 learning, in which the learners' interlanguage grammar is restructured as their attention is drawn to the form in the input. This is achieved through conscious attention to forms as advocated by the FFI approach (Gass, 2003; Nassaji, 1999; Schmidt, 1990). With regard to young learners, Ellis (2002), from his review of a number of studies, surmised that FFI was successful in the acquisition of implicit knowledge involving children in both oral and written production. He also found that FFI seemed to work best for simple morphological and formulaic structure with extended treatment, or complex syntactic features with opportunities for exposure outside the FFI lessons (Ellis, 2002).

In addition to the FFI lessons, a more personalized grammar instruction was implemented in this study by applying Corrective Feedback (CF). Indeed, feedback treatment is in reality part of FFI and is the spontaneous feature of FFI instruction in contrast to the planned lessons (Brown, 2007). FFI and Corrective Feedback $(\mathrm{CF})$ have found support in renowned researchers of young 
learners such as Spada and Lightbown (1993) who postulated that the two, integrated in activities with communicative focus, have the potential to support the acquisition of second language in both the short and long term (Hussein, 2004).

In broad terms, CF can be classified as 'recast' (the teacher repeats what the student has said by replacing the error with the correct form) and 'prompts' (the correct form is not supplied by the teacher but is elicited from the learners). 'Prompts' as one type of feedback, for example, receives its theoretical foundation in the interaction hypothesis (Long, 1996; Pica 1994), which purports that language acquisition occurs as learners negotiate meaning when faced with incomprehensibility. On the whole, it appears that error treatment helps the language learners principally by drawing the learners' attention on the gap between their production and the standard of the target language, thus moving them forward in their interlanguage stage (Edmondson, 1985). Previous studies on CF reported that the younger the learners, the more they will benefit from CF (Lyster \& Saito, 2010). For young learners, some proposed that 'recast' was effective (Mackey \& Oliver, 2002), while others argued that it is too subtle for children and recommended the 'prompt' type of feedback (clarification, metalinguistic, elicitation, and repetition) instead (Lyster, 2001, 2004). Lyster (2002) also found that recast is more beneficial for correcting unknown linguistic form while prompts is helpful to elicit forms that students are familiar with (Lyster, 2004). Concerning other variables affecting the application of CF, Lyster (1998) suggested that prompt might be preferable for grammatical and lexical error as compared to recast. Several studies also concurred on the advantages of using prompt rather than recast for less proficient language learners (Hampl, 2011).

\section{METHOD}

The participants of this study were eleven students aged 5-6 years old at K2 level of one intact class called Lavender Class of Pre-school X. For ease of analysis, the students were managed into four groups based on selected traits which were deemed to be relevant to this study. Group A consisted of four students who were academically excellent as active English speakers except for one, with sufficient exposure to English outside of school. The two students in group B were also active English speakers, although their academic performance and English exposure outside of school were less than those of group A. 
Group C students, made up of Ben and Mike (pseudonyms only), stand out from the rest due to their particularly talkative nature. Lastly, there were three students in group D who, in spite of their fairly talkative nature, were rather poor in terms of their academic performance and English exposure outside school.

The Grammar teacher of the K2 classes acted as the collaborator in this study, and was provided with the FFI materials, techniques, and CF methods of teaching Grammar as required for this research. One of the researchers assumed the role of the observer to perceive students' grammatical accuracy from their speech, and also interacted with the students in and outside of lesson time in order to provide $\mathrm{CF}$ to the students or to elicit some speech production.

As the main objective of this study is to describe some interventions used by the teacher in order to improve a particular linguistic aspect of the students in a classroom, Classroom Action Research (CAR) was deemed to be the most appropriate methodology. This study was carried out in four phases of activities within three cycles; namely, Planning, Action, Observation, and Reflection. During the Planning phase, the focus of grammatical aspect was decided on (1) pluralization; (2) personal pronouns; (3) auxiliary do/does; and (4) irregular past tense verb as they seemed to correspond to both the needs of the students and the timing for their acquisition (Pienemann, 1998, 2005). Consequently, instructional materials were prepared for each of the grammatical aspects, as follows: (1) Pluralization: One Banana Two Bananas video-song from YouTube and Fruits and Stationary exercises (self-developed); (2) Personal pronouns: I am Hungry video-song from YouTube and Card drill (Nixon and Tomlinson, 2003); (3) Auxiliary do/does: Do You Like Broccoli Ice Cream video-song from YouTube and A Question of Taste (Nixon and Tomlinson, 2003); and (4) Irregular past forms: My Last Weekend story (self-developed). Those materials were incorporated within a lesson plan that was modeled after Batstone's (1994) procedure, namely noticing, structuring, and proceduralizing. During the teacher's training, the Grammar teacher was briefed on FFI techniques and the prepared materials, as well as the different types and usage of CF for this study.

The Action phase consisted of the FFI Grammar instruction and the CF application when needed. While the provision of CF was an on-going process, the FFI lessons were implemented in three cycles as follows: (1) Cycle one (819 April 2013) focused on the use of regular plural form (-s and -es). The lessons were divided into two sessions; one for the 'noticing' and 'structuring' 
phase, another for the 'proceduralizing' phase; (2) Cycle two (29 April - 10 May 2013) dealt with subject pronoun and simple present tense (the usage of do/does) in two sessions, one for each grammar aspect; and (3) Cycle three (13 - 24 May 2013) concentrated on the use of irregular past tense form (went, saw, met, drank, went) in one session.

In the Observation Phase, the students' English speeches were observed and noted with occasional supplements of video/audio recording in order to obtain some permanent records. Hence, the primary data were collected through observation and recording, with the aid of field notes and video/audio equipments respectively. For a quick check on the grammatical aspects acquired and not acquired for each student, an observation checklist was also employed. This checklist was also useful to see if any particular student was lacking speech samples for certain grammatical topics, so that some purposeful elicitation could be done. Moreover, document analysis, as secondary data, was also carried out through examining the students' Grammar worksheets. Other secondary data include audio-recording of the interviews with the Grammar teacher and the researcher's journals.

Data collection process ran from April to June 2013 for a period of 10 weeks, or one term as is referred to in the school's academic calendar. All of the five FFI lessons were taped with the video camera, and a few other selected lessons were recorded using the audio recorder. At the end of each FFI lesson, a short journal serving a reflection and description of the lesson just carried out was written, and the Grammar teacher was interviewed for her opinion of it. Besides, results from the worksheets were analyzed briefly to gauge the assimilation of grammatical points taught. Samples of the students' speech containing both positive and negative samples of the grammatical points just taught were recorded in the observation sheet daily, together with the $\mathrm{CF}$ given whenever applicable. At the end of each cycle, all the data gathered were analyzed in a summarized manner, in order to find out any points that can contribute to the next cycle. Uncertainties in the data were cross-checked with the Grammar teacher when possible. The schedule of the data collection phase for the entire cycle is tabulated in Table 1.

Finally, in the Reflection Phase, the data gathered were analyzed for aspects that could contribute to the next cycle and/or to the research as a whole. The video/audio recordings, as well as hand-written notes, were first transcribed in digital form using Microsoft Word $\AA$ and Excel ${ }^{\circledR}$. Next stage is the data reduction process (Miles and Huberman, 1984) in which the transcribed 
data were paraphrased, summarized, organized, and categorized to facilitate noticing of patterns that might emerge. In this study, organizing the data per grammatical topics, and further divided them for each student, was deemed to be the most effective and informative. This was followed by data analysis; a closely-knit process that continuously follows the data (Richards, 2003). Certain themes, patterns, and issues that emerged from the data collection process were noted and reflected upon. Primarily, samples of students' utterances before and after the FFI lessons were compared in order to find out if any improvement has resulted, and what could be the cause of such success or failure.

Table 1. Schedule of Data Collection

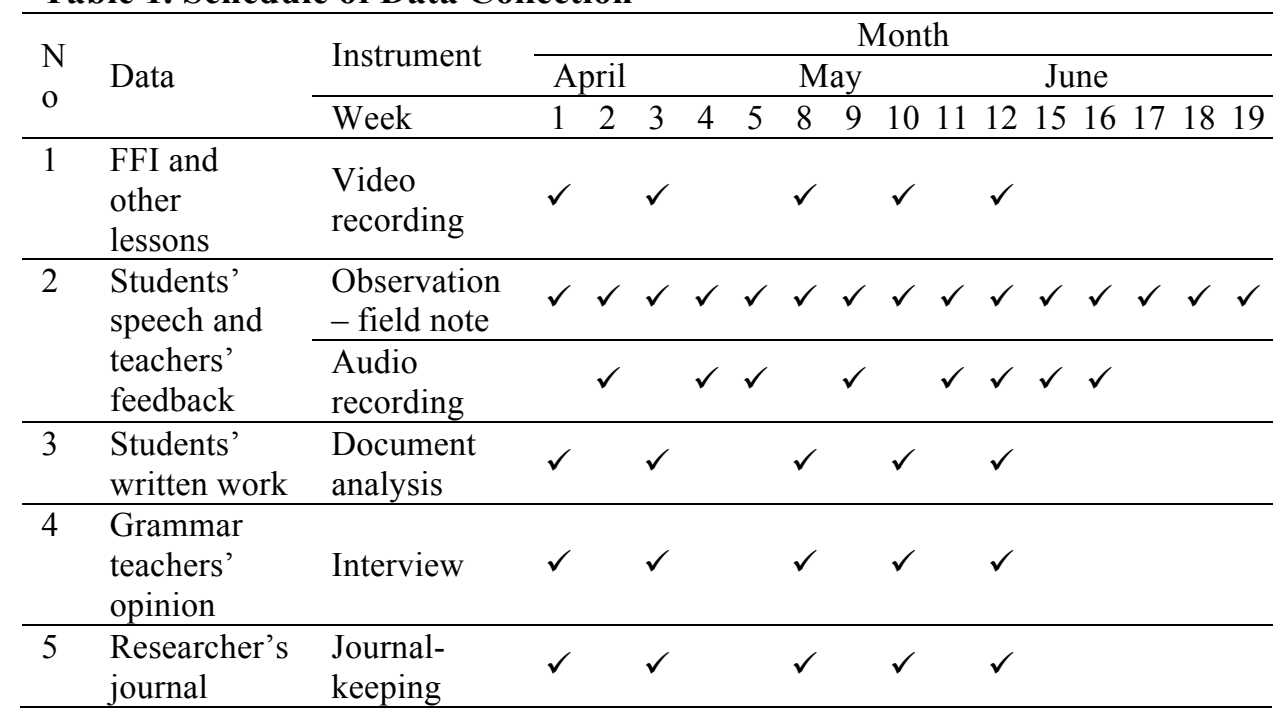

\section{FINDINGS AND DISCUSSION}

\section{Findings}

For the purpose of giving some numerical assessment, a rudimentary scoring system was devised in which, for each grammatical form taught, an average of the class' improvement of that grammatical form was computed. From the various data gathered, mainly the students' speech samples before and after the lesson and the worksheet result, each student was given a score from (1) to (4). 
The score is based on the following analytical rating rubric tabulated in Table 2.

Table 2. Scoring Rubric for the Students' Grammatical Improvement

\begin{tabular}{|c|c|c|c|c|}
\hline Score & 4 & 3 & 2 & 1 \\
\hline \multirow{3}{*}{ Traits } & $\begin{array}{l}\text { Responsive } \\
\text { during lesson }\end{array}$ & $\begin{array}{l}\text { Attentive during } \\
\text { lesson }\end{array}$ & $\begin{array}{l}\text { Attentive during } \\
\text { lesson }\end{array}$ & $\begin{array}{l}\text { Inattentive during } \\
\text { lesson }\end{array}$ \\
\hline & $\begin{array}{l}\text { Worksheet done } \\
\text { perfectly }\end{array}$ & $\begin{array}{l}\text { Worksheet done } \\
\text { quite perfectly }\end{array}$ & $\begin{array}{l}\text { Worksheet done } \\
\text { quite perfectly }\end{array}$ & $\begin{array}{l}\text { Mistakes in } \\
\text { worksheet }\end{array}$ \\
\hline & $\begin{array}{l}\text { No/insignificant } \\
\text { errors in speech } \\
\text { samples after } \\
\text { lesson }\end{array}$ & $\begin{array}{l}\text { Very few errors } \\
\text { in speech } \\
\text { samples after } \\
\text { lesson }\end{array}$ & $\begin{array}{l}\text { Mixture of } \\
\text { erroneous and } \\
\text { correct speech } \\
\text { samples }\end{array}$ & $\begin{array}{l}\text { Mainly erroneous } \\
\text { speech samples }\end{array}$ \\
\hline
\end{tabular}

For each topic, the students' improvement was calculated based on their scores and was computed using a formula (Figure 1) to have percentage for their performances. For example, if the total score was 27 and there were samples from 10 students, the percentage would be $27 / 40 \times 100 \%=68 \%$.

Sum of the scores for all students for a topic

$4 \times($ total number of students $)$

Figure 1. Formula to Calculate Students' Improvement

For plural form, only one student showed notable improvement after the FFI plural lesson. Five other students were able to employ the plural form in their daily speech most of the time and were sensitive to correction. Most of the time, the rest of the students were still unable to apply the plural form yet in their daily conversation or did not show sign of comprehension of the form. With all these, the rudimentary score given to the students' improvement in this topic was set at $61 \%$, or that each student reached an average score of 2.45 . Despite the low score, the FFI plural lesson managed to effect the most changes in the students in that more students exhibited greater awareness of the plural form even though they did not manage to master it perfectly. The students' speech samples showed that five students displayed the changes from not knowing anything about the plural concept to being able to provide repair upon correction. In the interview, the Grammar teacher herself was quite impressed with how the students were made more conscious of the plural forms after only few lessons. It could be postulated that, since the regular plural structure was 
taught in two lessons, it is possible that this fact contributed to the success in promoting that awareness. Chuang (2009) pointed out that FFI instructions facilitate the change in the learners' interlanguage system by storing the intake in the 'analytic rule-based system', due to the noticing of the new rule being taught. Perhaps, due to the more extensive coverage of the plural form, more changes in the interlanguage system of the students were accounted for. In this way, this study then seemed to support the observation made by Ellis (2002) that the success of FFI instruction in children depends on the target structure and the extent of instruction in which FFI appeared to work best for simple morphological and formulaic structure with extended treatment.

For subject pronouns, more students appeared to be able to use them, especially 'she', correctly. Two students seemed to have mastered it, four still made mistakes occasionally but were sensitive to correction, three did not show consistency in their speech, and only one student did not appear to comprehend the concept of grammatical gender. Overall, the score for this topic was $68 \%$, or an average score of 2.7 per student.

The analysis for the auxiliary do/does topic yielded a score of $63 \%$ (2.5 for each student). During the analysis, although three students showed good mastery of the usage in their daily speech and two were deemed to be fairly good, the students' mastery of the auxiliary 'does/doesn't' proved to be difficult for the rest of the students. Two students who were particularly talkative persistently made mistakes in the use of 'does/doesn't'. The rest of the students did not show sign of comprehending the concept.

Lastly, the result for the Irregular Past Tense Verbs lesson was quite promising. Generally speaking, it looked as if all students basically understood that different forms of verb is required when speaking about something in the past, even the students who were not-so-academically inclined and did not seem to get other grammar points. The rest of the students could by-and-large applied the usage of irregular past tense form when telling stories, with five students perceived to have mastered it quite well. The assessment for the students' performances yielded $80 \%$ or a score of 3.2 on average. This success could be attributable to the fact that the past tense form was also reinforced by the teachers through positive modeling in other lessons apart from Grammar. Another reason could be the overt marking of the 'root changes' (e.g., go-went) involved in the irregular past tense forms (Hakuta, 1976) which the students detected in their teachers' input during the lessons. Since children will acquire earlier the input with more overt morphological markers (Slobin, 1971), they 
will find it easier to master irregular past tense verbs than, say, the suffixing of $-\mathrm{s}$ in plural nouns.

The document analysis helped to confirm the findings. For example, the result of the plural form worksheets revealed that the students were struggling to grasp the plural concept as indicated in Table 3.

Table 3. The Students' Results of the Plural Form Worksheets

\begin{tabular}{lllll}
\hline $\begin{array}{l}\text { Mistakes on the } \\
\text { addition of 's/es' } \\
\text { (fruits) }\end{array}$ & $\begin{array}{l}\text { No mistake } \\
\text { (without } \\
\text { guidance) }\end{array}$ & $\begin{array}{l}\text { No mistake } \\
\text { (with guidance) }\end{array}$ & $\begin{array}{l}\text { One } \\
\text { mistake }\end{array}$ & $\begin{array}{l}\text { Two or more } \\
\text { mistakes }\end{array}$ \\
\hline $\begin{array}{l}\text { Number of } \\
\text { students }\end{array}$ & 1 & 4 & 3 & 1 \\
\hline
\end{tabular}

On the other hand, the result from the auxiliary do/does worksheets showed that most of the students seemed to comprehend the concept, at least in writing, as depicted in Table 4.

Table 4. The Students' Results of the Auxiliary do/does Worksheets

\begin{tabular}{lllll}
\hline $\begin{array}{l}\text { Mistakes on the } \\
\text { do/does }\end{array}$ & No mistakes & $\begin{array}{l}\text { Mistakes in } \\
\text { 'don't' }\end{array}$ & $\begin{array}{l}\text { Mistakes } \\
\text { in 'does' }\end{array}$ & $\begin{array}{l}\text { Incomplete } \\
\text { work }\end{array}$ \\
\hline $\begin{array}{l}\text { Number of } \\
\text { Students }\end{array}$ & 7 & 1 & 1 & 1 \\
\hline
\end{tabular}

To reflect on how the FFI lessons could have contributed to the students' improvement (or the lack of it) in their spoken English, the secondary data were used to supplement the primary. In the interview with the Grammar teacher, she was asked about what feature of the FFI lessons contributed most to the students' learning, she stated that it was the use of the video. In her own words, she said, "The visualization of the video really helped the students to be engaged with the grammar point. It makes the students easier to catch or to get the point taught at that time."

In the plural lesson, she endorsed the use of realia to support learning, such as the use of plastic fruits for the students to describe in plural form. She saw then that the students were really excited since they could "see the real object". As she herself commented,

"Every single one of them wanted to answer the question, without them realizing that it's a drill. That's a practice, right? I think it's really good." 
For the irregular past tense verb topic, the teacher was in agreement with the researcher that the use of 'My Last Weekend' story as the noticing media was successful since it is a familiar occurrence to the students. Overall, she commented the following:

"I think they have improved their ability to use past simple, especially when they were talking about what happened before, and they really like ... to show me that they have got it, that they have understood the past simple, saying like, 'Miss, I went here, I saw him, I saw her, I did this, I did that...' I think it was really successful..."

\section{Discussion}

Hence, based on the data related to grammatical improvement analysis supported by the supplementary data, the following discussion points were reached. Generally, it can be said that the lessons inspired by FFI strategy have benefited the students in group A in the four grammatical features imparted. The speech samples taken from them after the FFI lessons were mostly acceptable. However, given that the students in group A are so-to-speak bright students, it is not easy to pinpoint specifically how FFI lessons could have contributed to the improvement of their spoken English. It can be postulated that the key might lie in the 'noticing' part of the lessons (songs with graphic enhancement) which was absent when the Grammar teacher taught the same grammatical forms previously. Another feature of FFI lessons that was absent was the 'proceduralizing' stage wherein the students applied the structures learned in a freer production sort of activities.

Students of group B have also improved somewhat in their spoken English of the four topics after the FFI lessons. Just like those of Group A, these Group B students might also be helped by similar features of the FFI lessons that were absent in the previous activities, non-FFI lessons. However, perhaps because academically they are not as brilliant as those in group A, coupled with the fact that they have little English exposure outside of school, they did not show as stable improvements as group A students.

Student Mike of group C generally excels academically but, unlike students in group A, he had particular difficulties with Plural form and the auxiliary Do/Does, employing 'do/don't' persistently for female singular pronoun. The Grammar teacher commented that he seemed to understand the lesson and 
the video recording showed him to be participating actively. This learning, however, was not transferred to speaking. It appeared then, that the FFI lessons, at least the Plural and Auxiliary Do/Does lessons, did not influence much improvement in him. It can be postulated that the reason lies in both/either the lessons which were not carried out in the way that would have helped him, and/or the student himself. Paradis (2005), when comparing ESL children and monolingual children with Specific Language Impairment (SLI), found that both exhibited the same commission errors by the use of 'do' when the context required 'does', although no explanation of the reason was given. It could only be conjectured that Mike, perhaps not unlike those SLI children, has a special difficulty with the bi-syllabic form of 'doesn't' and the whole paradigm of subject-verb agreement that he subconsciously avoided the use of 'doesn't' and 'does'.

In the same way, student Ben also struggled with specific grammar forms, namely plural form and grammatical gender difference. It was noted that he was absent in one of the plural form lessons, and he had to be helped in doing the worksheet of the Subject Pronoun lesson. He also seemed to have difficulties saying 'she' for females. Just like student Mike, the reason for this might be extrinsic (the FFI lessons, the CF) and/or intrinsic. For the latter, perhaps personally he is not developmentally ready for the concept of grammatical gender distinction, which made him rather impervious to both the FFI lessons and CF. Ellis and Sheen (2006) classified it as one of the Learners' Factors variable that mediates the effectiveness of CF. It should also be noted that he is the youngest student in class. The absence of the equivalent form in the L1 (Bahasa Indonesia uses the same word 'dia' as pronoun for both male and female third person singular) might have added to his struggle.

Finally, the FFI lessons seemed to have only limited impact on students in group D. They hardly paid attention during the lessons, and mostly had to be guided when answering and completing their worksheets. Thus, there was not much change in their non-standard spoken English before and after the FFI lessons. Nevertheless, it could be said that the songs and the realia used in those lessons helped to get their attention and heighten their awareness of the target forms. Apart from this, the FFI lessons might not have helped them much since their cognitive ability is perhaps still developing so they were not ready yet for those structures.

When it comes to $\mathrm{CF}$, overall the plural form was where most CF was given in the most varied form including metalinguistic feedback and elicitation. 
For subject pronoun, the speech samples taken from the students that showed both positive and negative usage of subject pronoun were not that many. It might indirectly prove that the majority of the students could employ subject pronouns correctly, since they did not sufficiently call the attention of the researcher for their speech samples to be recorded. On the contrary, there were many speech samples collected for the use of auxiliary do/does. This was perhaps because student Mike, who was a particularly talkative student, made a lot of mistakes of this type as was discussed previously. The speech samples collected on irregular past tense verbs were rather encouraging; there were signs that the students grasped the lesson well and could apply it almost immediately in their daily conversation. Consequently, the samples of CF given on this topic were few and far between.

For students in group D, it was observed generally that CF did not have significant contribution to the spoken English of those students. They might not be very perceptive towards correction as they do not notice the gap between their speech production and the target language, since they have not grasped the target language in the first place. On the choice of CF, they were given mostly recast since it was thought that they were not able to produce their own repair. However, Ammar and Spada (2006) found that students who did not perform well in the pretest responded better with prompt than recast. Similarly, Hampl (2011) also noted that the teacher in her study preferred the use of metalinguistic feedback (a type of prompt) for students who were not highly proficient in the L2, since they were still thinking in terms of language rules (Hampl, 2011). Hence, since this study ultimately showed that the recast did not bring about significant improvement for those students, it might provide an indirect support to those reported by Ammar and Spada (2006) and Hampl (2011).

Next, it was noted that CF seems to make a positive contribution to students in group $\mathrm{C}$, namely Mike and Ben; there were samples in which they were corrected on one aspect before, and they did not repeat the same mistake on the same aspect. It can be conjectured that, since both of them are rather talkative, CF has a positive impact on them since they have many chances to do 'trial and error'; making hypothesis about the language aspect learned, and testing it through usage in conversation. The feedback given would have confirmed that their hypothesis was incorrect, and the absence of it might be construed as correct hypothesis. This outcome could also be a corroboration of the result reported by Havranek and Cesnik (2001), who found that learners who 
enjoy speaking English benefit more from CF. In a rudimentary way, this is a further support for Long's interaction hypothesis, who stated that linguistic rules are developed through conversation and interactive communication (Brown, 2007).

Similarly, CF also appeared to have contributed to some improvement in the spoken English of the students in group B. There were records in which both students did not repeat the same mistakes after CF were given. Just like group $\mathrm{C}$, it could also be said that they largely benefit from $\mathrm{CF}$ due to their rather talkative nature, coupled with their fairly good academic performance, which help them to both notice the gap in their oral performance and make repairs upon correction.

Lastly, there was hardly a need for CF to be given for students in group A as they were, in broad terms, able to apply what they had learned in the lessons in their spontaneous speech. They were all generally sensitive to the corrections and were able to self-correct. It was also noted that one of them made an improvement in the use of the auxiliary 'does' after being corrected, even before both the FFI lesson on that topic were given. Just like in the case of FFI lessons, it is not easy to pinpoint how CF could have benefited the students in group A. It could be said in general that they did not need the CF since the FFI lessons alone were sufficient for their learning of the forms taught.

Figure 2 depicts the graph showing the frequency of each $\mathrm{CF}$ in percentage form and the rate of uptake/repair for each type of feedback.

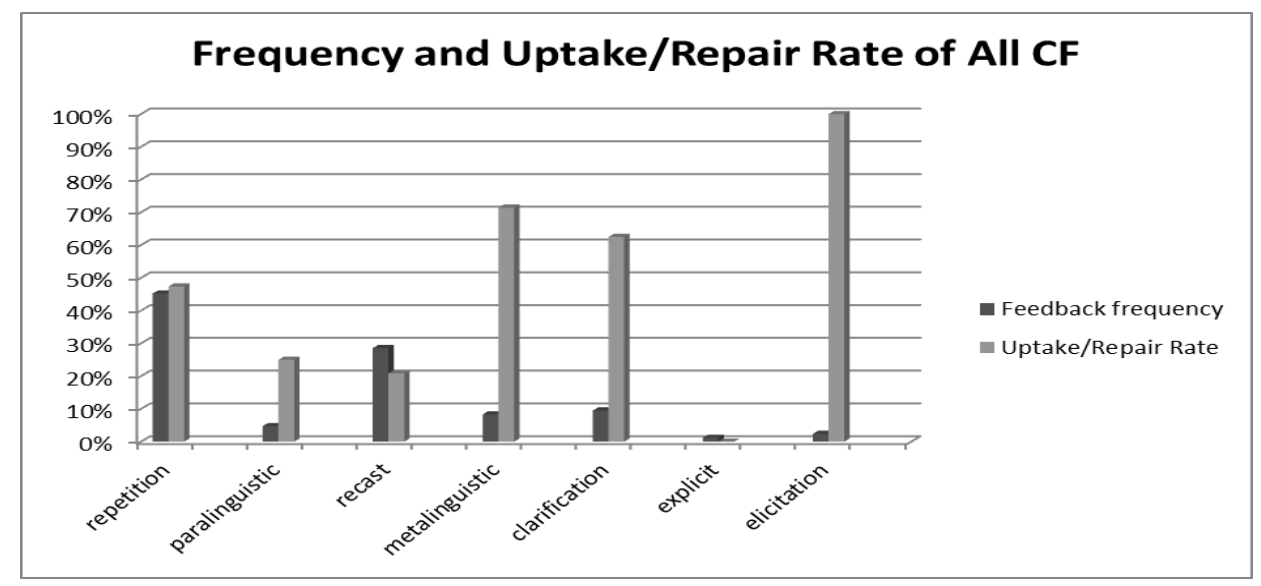

Figure 2. Frequencies and Uptake/Repair Rate of All CF 
Despite the lower rate of uptake for repetition in this study (47\%) compared to that of Lyster and Ranta's 80\% (1997), it was felt that the prompt type of feedback (including elicitation, metalinguistic feedback, clarification, etc.) should still be used in preference over recast as a means for facilitating language learning process. There were records in which students were corrected on specific grammatical points using repetition, and they subsequently could use the correct form spontaneously. This seemed to be consistent with Lyster's argument that the prompt type of feedback is generally more effective than recast in pushing the learners to notice the error, restructure their erroneous output, and store this in their long-term memory (Lyster, 2004). From the point of view of the acquisition principles, prompts are beneficial in transforming mere declarative knowledge into procedural knowledge as the learners gain better mastery over already known forms (Lyster, 2004). The choice of prompts over recast was also based on Lyster's previous finding (Lyster, 1998) that prompt resulted in more immediate repair for grammatical errors, which was the focus of this study. Lastly, the advantage of prompt over recast as reflected in this study is also consistent with the result reported by Lyster wherein FFI lessons with prompt outperformed that with recast in oral tasks' immediate posttest. Moreover, the results of this study suggest that prompt facilitates the retrieval of grammatical rules in the short-term memory (Lyster, 2004).

\section{CONCLUSIONS AND SUGGESTIONS}

With regard to the contribution of FFI strategy in the effort to improve the accuracy of the kindergarten students' spoken English, the analysis revealed that FFI strategy improvement in greater or lesser degree depends on the (English) language proficiency of the students and their general academic performance, with some exceptions noted in two students. Similarly, the implementation of CF influences the students' academic performance (with the same exceptions for the two students) although this study indicates that the more talkative students seemed to benefit more from CF. The Irregular Past Tense topic was the most 'successfully' improved, which could be attributed to the use of the storytelling, the 'Disappearing Words' drill, and the positive modeling. Although the result for the Regular Plural form seemed dismal, it was deemed to result in most awareness in the students due to extensive treatment of the topic and the use of a catchy song as the 'noticing' media. 
Researchers in the TEYL fields might want to pursue the same subject with studies of more experimental nature, in order to give a quantitative support to this study. Alternatively, a similar CAR type of research under this theme could also be carried out for other aspects of acquisition (e.g. lexical, semantical, phonological) or other grammatical topics such as prepositions and articles.

\section{REFERENCES}

Ammar, A., \& Spada, N. (2006). One size fits all?: Recasts, prompts, and L2 learning. Studies in Second Language Acquisition, 28(4), 543-574.

Batstone, R. (1994). Grammar. Oxford: Oxford University Press.

Brown, D. H. (2007). Principles of language learning and teaching. New York: Pearson Education.

Chuang, Y.-Y. (2009). A comparison of the effectiveness of focus-on-form and meaning-focused instructions in the English classroom. Journal of TOKO University, 4(2), 104-122.

Edmondson, W. J. (1985). Discourse worlds in the classroom and in foreign language learning. Studies in Second Language Acquisition, 7(2), 159-168.

Ellis, R., \& Sheen, Y. (2006). Reexamining the role of recasts in second language acquisition. Studies in Second Language Acquisition, 28(4), 575600 .

Ellis, R. (2002). Does form-focused instruction affect the acquisition of implicit knowledge? A review of the research. Studies in Second Language Acquisition, 24(2), 223-236.

Hakuta, K. (1976). A case study of a Japanese child learning English as a second language. Language Learning, 26(2), 321-351.

Havranek, G., \& Cesnik, H. (2001). Factors affecting the success of corrective feedback. EUROSLA Yearbook, 1(1), 99-122.

Gass, S. M. (2003). 9 Input and interaction. In C.J. Doughty and M.H. Long (Eds.), The handbook of second language acquisition, (pp. 224-253). Cornwall: Blackwell Publishing Ltd. 
Hampl, M. (2011). Error and error correction in classroom conversation: A comparative study of CLIL and traditional lessons in Austria. Vienna: University of Vienna.

Hussein, H. (2004). Using simple poems to teach grammar. The Internet TESL Journal, 10(5). Retrieved from http://iteslj.org/Techniques/HusseinPoems.html

Long, M. H. (1996). The role of the linguistic environment in second language acquisition. In W.C. Ritchie \& T.K. Bhatia (Eds.), The handbook of second language acquisition, (pp. 413-468). San Diego, CA: Academic Press, Inc.

Lyster, R. (1998). Negotiation of form, recasts, and explicit correction in relation to error types and learner repair in immersion classrooms. Language Learning, 48(2), 183-218.

Lyster, R. (2002). Negotiation in immersion teacher-student interaction. International Journal of Educational Research, 37(3), 237-253.

Lyster, R. (2004). Differential effects of prompts and recasts in form-focused instruction. Studies on Second Language Acquisition, 32(2), 399-432.

Lyster, R., \& Ranta, L. (1997). Corrective feedback and learner uptake. Studies in Second Language Acquisition, 19(1), 37-66.

Lyster, R., \& Saito, K. 2010. Oral Feedback in Classroom SLA: A Meta Analysis. Studies in Second Language Acquisition, 32(2), 265-302.

Mackey, A., \& Oliver, R. (2002). Interactional feedback and children's L2 development. System, 30(4), 459-477

McLaughlin, B. (1987). Theories of second-language learning. London: Edward Arnold.

Miles, M. B., \& Huberman, A. M. (1984). Qualitative data analysis: a sourcebook of new methods. Beverly Hills: Sage Publications.

Nassaji, H. (1999). Towards integrating form-focused instruction and communicative interaction in the second language classroom: Some pedagogical possibilities. Canadian Modern Language Review/La Revue canadienne des langues vivantes, 55(3), 386-402. 
Nixon, C., \& Tomlinson, M. (2003). Primary grammar box. Cambridge: Cambridge University Press.

Paradis, J. (2005). Grammatical morphology in children learning English as a second language. Language, Speech, and Hearing Services in Schools, $36(3), 172-187$.

Pica, T. (1994). Research on negotiation: What does it reveal about second-language learning conditions, processes, and outcomes? Language Learning, 44(3), 493-527.

Pienemann, M. (1998). Language processing and second language development: Processability theory. Amsterdam: John Benjamins Publishing.

Pienemann, M. (2005). An introduction to processability theory. In M. Pienemann (Ed.), Cross-linguistic aspects of processability theory (pp. 1-60). Amsterdam and Philadelphia: John Benjamins Publishing Company.

Richards, K. (2003). Qualitative inquiry in TESOL. Basingstoke: Palgrave Macmillan.

Schmidt, R. W. (1990). The role of consciousness in second language learning1. Applied Linguistics, 11(2), 129-158.

Slobin, D. I. (1971). Developmental psycholinguistics. In W.O. Dingwal (Ed.), A survey of linguistic science, (pp. 298-411). College Park: M.D: University of Maryland Linguistics Program.

Spada, N., \& Lightbown, P. M. (1993). Instruction and the development of questions in L2 classrooms. Studies in Second Language Acquisition, 15(2), 205-224.

Spada, N., \& Lightbown, P. M. (1994). An innovative program for primary ESL students in Quebec. TESOL Quarterly, 28(3), 563-579. 